\title{
Viewpoint
}

\section{B27 positive diseases versus B27 negative diseases}

\author{
A LINSSEN AND T E W FELTKAMP \\ From the Netherlands Ophthalmic Research Institute, Amsterdam
}

Key words: ankylosing spondylitis, Reiter's syndrome, reactive arthritis, acute anterior uveitis, HLA-B27.

Of all the known associations between HLA and diseases, the association of B27 with ankylosing spondylitis (AS) is the strongest. The B27 antigen is present in over $90 \%$ of patients with AS as compared with the B27 prevalence of $8 \%$ in Caucasians in general. A strong but slightly minor association has also been found between B27 and Reiter's syndrome (RS), reactive arthritis $(\operatorname{Re} A)$, and acute anterior uveitis (AAU). These diseases are so strongly interrelated, especially in the presence of B27, that one may speak of 'B27 associated diseases'. ' Many authors regard psoriatic arthritis, also, as a disease associated with B27. ${ }^{2-4}$ For reasons which will be discussed below, however, we consider B27 to be associated mainly with the spondylitic part of psoriatic arthritis and not with psoriatic arthritis in general, as others have suggested. ${ }^{5-8}$

The aetiology of these diseases remains elusive. Interaction of environmental and genetic factors has been postulated; nevertheless, a decade after the landmark results on HLA-B27 and its associated diseases $^{69}$ the nature of the mechanisms underlying these associations is still subject to much speculation.

The association of B27 with its associated diseases is far from complete. This could be explained if, besides B27, other genes near the B locus on chromosome 6 , or on other chromosomes, were involved in the pathogenesis. ${ }^{10-12}$ From epidemiological and family studies other genetic factors have also emanated to explain the observed incomplete association. ${ }^{1314}$ None of the studies of genetic factors in the pathogenesis of AS, however, clearly

Accepted for publication 1 October 1987.

Correspondence to $\mathrm{Dr} \mathrm{A}$ Linssen, Netherlands Ophthalmic Rescarch Institute, PO Box 12141, 1100 AC, Amsterdam, The Netherlands. indicated genes other than B27. ${ }^{1012}$ Nor did any of the B27 subtypes show a particular association with AS. ${ }^{15-18}$

Strong evidence for B27 as the major genetic susceptibility factor is found in detailed population and family studies, in which no stronger association has been observed other than that between B27 and AS. A stronger B27 association has been found in Caucasians with spondylitis than in their American black counterparts. ${ }^{19}$

In addition to genetic factors, infectious agents have been regarded as a likely cause of primary AS. Several studies by Ebringer $e$ t al strongly suggested Klebsiella pneumoniae in this respect, ${ }^{20}$ but other authors could not confirm their results. ${ }^{21}$ In reactive arthritis clear cut evidence for causative infectious organisms of urinary and enteric origin have been demonstrated.

In the cases where HLA-B27 is considered to play a part in the pathogenesis of B27 associated diseases, B27- AS, B27- RS, B27- ReA, and B27- AAU are probably the same diseases, but developing along different lines. We have attempted to solve this problem by comparing the clinical pictures of $\mathrm{B} 27^{+} \mathrm{AS}, \mathrm{B} 27^{+} \mathrm{RS}, \mathrm{B} 27^{+} \mathrm{ReA}$, and $\mathrm{B} 27^{+} \mathrm{AAU}$ with those of their B27- counterparts.

A review of the literature is given together with the observations made by our own group.

\section{$\mathrm{B27}^{+} \mathrm{AS}$ versus $\mathrm{B27}^{-} \mathrm{AS}$ (Table 1)}

In the first study on the heterogeneity of AS in black patients Good et al observed more serious disease in seven who were HLA-B $27^{+}$than in nine who were HLA-B27 ${ }^{-22}$ In this study no clinical details were given. Khan et al studied clinical differences of $\mathrm{B} 27^{+}$ and B27- black and Caucasian patients with AS. ${ }^{23} 24$ 
Table 1 Differences between $B 27^{+} A S$ and $B 27^{-} A S$

\begin{tabular}{|c|c|c|c|c|c|}
\hline \multirow[t]{2}{*}{ Clinical details } & \multirow[t]{2}{*}{ Reference } & \multicolumn{2}{|l|}{ B27 positive ${ }^{*}$} & \multicolumn{2}{|l|}{ B27 negative* } \\
\hline & & Number studied & Prevalence (\%) & Number studied & Prevalence (\%) \\
\hline Age of onset & 29 & 95 & 24 (years) & 20 & 38 (years) \\
\hline Peripheral arthritis & 28 & 88 & 38 & 7 & 14 \\
\hline Peripheral arthritis & 29 & 95 & 55 & 20 & 15 \\
\hline Bamboo spine & 28 & 88 & 22 & 7 & 0 \\
\hline AAU & 25 & 50 & 28 & 12 & 0 \\
\hline AAU & 29 & 95 & 41 & 20 & 15 \\
\hline AAU & 30 & 128 & 17 & 17 & 6 \\
\hline Inflammatory bowel disease & 29 & 95 & 1 & 20 & 9 \\
\hline Psoriasis & 8 & 112 & 12 & 10 & 60 \\
\hline Family history & 27 & 170 & + & 17 & - \\
\hline Family history & 30 & 128 & + & 17 & - \\
\hline
\end{tabular}

*AAU $=$ acute anterior uveitis.

They did not find any difference of age at onset, functional class, degree of deformity, $x$ ray abnormalities, or the prevalence of peripheral arthritis. The only difference was an increased prevalence of a history of AAU in $\mathrm{B} 27^{+} \mathrm{AS}$ patients compared with B27- AS patients. This study was confirmed by Nahir and Scharf, who found AAU in B27 AS patients only. ${ }^{25} 26$ Van der Linden et al discovered no clinical differences at all. ${ }^{27}$ They found AAU in both $\mathrm{B} 27^{+}$and $\mathrm{B} 27^{-}$patients. All the patients with AS who had a family history of AS were B27 ${ }^{+} .27$

Gerber et al observed arthritis of the shoulders and lower extremities and the development of a 'bamboo spine' slightly more often in $\mathrm{B} 27^{+} \mathrm{AS}$ than in $\mathrm{B} 27^{-} \mathrm{AS}$ patients. ${ }^{28}$

On the other hand, the data of Dekker-Saeys, ${ }^{29}$ Woodrow and Eastmond, ${ }^{30}$ Møller et al, ${ }^{8}$ and Wagener $e t a l^{31}$ did show clinical differences. In B27 $7^{-}$disease they found a later onset of AS, milder in its course in respect of the development of a bamboo spine, and thus less aggressive in appearance and subsequently with a better prognosis. They observed more psoriasis and inflammatory bowel disease (IBD) in $\mathrm{B}^{2} 7^{-} \mathrm{AS}$ and more peripheral arthritis and acute anterior uveitis in $\mathrm{B} 27^{+} \mathrm{AS}$. Family aggregation was seen in $\mathrm{B} 27^{+} \mathrm{AS}$ only. ${ }^{27}{ }^{30}$

Constant findings by nearly all authors were the positive family history of $\mathrm{AS}$ and the development of AAU, mostly in $\mathrm{B} 27^{+} \mathrm{AS}$ patients.

The discrepancies of the various studies are certainly due to patient selection. In those studies in which no clinical differences were observed between $\mathrm{B} 27^{+}$AS and $\mathrm{B} 27^{-}$AS the selection was made from well defined classical AS without associated diseases. In the studies of Dekker-Saeys, ${ }^{29}$ Møller et $a l^{8}{ }^{8}$ and Wagener et $a l^{31}$ AS associated with psoriasis and IBD were not excluded. Woodrow and
Eastmond did exclude psoriasis and IBD associated $\overline{3}$ with AS. ${ }^{30}$ They found five patients with peripheral arthritis resembling psoriatic arthritis. Three of $\overrightarrow{0}$ these were $\mathrm{B} 27^{-}$. One other $\mathrm{B} 27^{-}$patient had a $\underset{\infty}{\infty}$ sister with ulcerative colitis and AS and a mother with ulcerative colitis.

From these studies one may conclude that $\mathrm{B} 27^{+}$ AS and B27-AS - apart from AAU-are almost identical diseases, but that differences in the clinical picture are caused by the presence of psoriasis or IBD.

In $\mathrm{B} 27^{-} \mathrm{AS}$ patients genes other than B27 may provide susceptibility to the development of AS. Possible candidates for such a role are the B7CREG antigens ${ }^{32-36}$ and the antigens associated with psoriasis ${ }^{37}{ }^{38}$ and inflammatory bowel disease. ${ }^{39}$.

AS may develop in $\mathrm{B} 27^{-}$patients carrying genes associated with psoriasis or inflammatory bowel disease without showing clinical expression of the skin or bowel disease, as was mentioned earlier by Woodrow $^{38}$ and Khan et al. ${ }^{33}$ No firm association between such non-B27 B locus antigens and AS has $\frac{7}{2}$ been found until recently, however. ${ }^{4(-12}$

Two different clinical pictures of AS emanate o from the above-mentioned studies, as has already $N$ been suggested by Dekker-Saeys in $1976 .^{29}$ (a) N Primary or idiopathic AS, developing early in genetically predisposed persons, triggered by unknown endogenous or exogenous factors, probably $\stackrel{0}{=}$ infective in origin. These patients are mostly $\mathrm{B} 27^{+}$. $\mathbb{\Phi}$ (b) Secondary AS, triggered by a primary disease, for instance a genital or gut infection, inflammatory bowel disease, or psoriasis. In this group B27 is $\underset{\mathbb{D}}{\vec{D}}$ mostly negative.

Finally, it has to be kept in mind that psor- $\stackrel{\varnothing}{\varnothing}$ iasis $^{2} 543-46$ and IBD ${ }^{47} 48$ itself, even when accompanied by peripheral arthritis, are not associated $\delta$ 
with B27. Sacroiliitis without axial involvement in psoriasis is only slightly associated with B27. ${ }^{2} 44 \mathrm{In}$ patients with sacroiliitis without axial involvement and IBD no association with B27 has been found. ${ }^{29} 49$ When, however, spondylitis accompanies sacroiliitis in psoriasis or IBD the association with B27 is nearly as high as that seen in primary $\mathrm{AS}^{2} 34648$ In conclusion, one may state that AS seen in psoriasis or IBD must be considered to be of the primary form.

\section{${\mathrm{B} 27^{+}}^{+} \operatorname{ReA}$ versus $\mathrm{B27}^{-} \operatorname{ReA}$}

Yersinia (Table 2)

The first reports of a significant association between B27 and arthritis triggered by an infection with yersinia came from Finland. ${ }^{50}{ }^{51}$ B27 was found in $80 \%$ of these patients with reactive arthritis, as was confirmed by others. ${ }^{52-54}$

Heterogeneity between $B 27^{+} \operatorname{Re} A$ and $B 27^{-} \operatorname{ReA}$ was studied by Aho et al. ${ }^{51}$ Table 2 shows that $\mathrm{B} 27^{+}$ patients often suffer from inflammation of more than one joint over a longer period of time, frequently complicated by sacroiliitis and AAU. These observations were confirmed by Laitinen et $a l^{53}$ and Leirisalo et $a l,{ }^{54}$ who also found more severe acute disease, including more frequent back pain, urological symptoms, and mucocutaneous manifestations, in $\mathrm{B} 27^{+}$patients than in their $\mathrm{B} 27^{-}$ counterparts. RS and AAU were observed in $\mathrm{B} 27^{+}$ patients only. The prevalence of erythema nodosum, however, was higher in $\mathrm{B}^{-} 7^{-}$patients (Table 2). In the long run $\mathrm{B} 27^{+}$patients had more chronic back pain than $\mathrm{B} 27^{-}$patients. $x$ Ray examination in the acute stage of the infection and at follow up showed development of sacroiliitis and spondylitis more often in $\mathrm{B} 27^{+}$patients.

Dequeker et al, from Belgium, made a study of 25 patients with yersinia arthritis and found no difference between $\mathrm{B} 27^{+}$and $\mathrm{B} 27^{-}$patients, ${ }^{55}$ but their numbers were small. The diagnosis of yersinia arthritis was based on raised agglutination antibody titres $(>1 / 100)$ and a typical history of oligoarthritis. Tests for the presence of the microbe in the patients or for rising antibody titres or IgA class antibody responses were not performed. They did not

Table 2 Differences between $\mathrm{B27}^{+}$and $\mathrm{B27}^{-}$reactive arthritis after yersinia infection

\begin{tabular}{|c|c|c|c|c|c|}
\hline \multirow[t]{2}{*}{ Clinical details } & \multirow[t]{2}{*}{ Reference } & \multicolumn{2}{|l|}{ B27 positive } & \multicolumn{2}{|l|}{ B27 negative } \\
\hline & & Number studied & Prevalence (\%) & Number studied & Prevalence (\%) \\
\hline Men & 53 & 49 & 51 & 25 & 24 \\
\hline Duration $<1$ month & 51 & 43 & 13 & 6 & 67 \\
\hline Duration $<1$ month & 52 & 31 & 15 & 17 & 41 \\
\hline Duration $<1$ month & 53 & 49 & 8 & 25 & 40 \\
\hline Duration $>2$ months & 51 & 43 & 51 & 6 & 0 \\
\hline Duration $>3$ months & 52 & 31 & 59 & 17 & 12 \\
\hline Duration $>3$ months & 53 & 49 & 45 & 25 & 24 \\
\hline Monarthritis & 51 & 43 & 14 & 6 & 50 \\
\hline Monarthritis & 52 & 31 & 6 & 17 & 18 \\
\hline Monarthritis & 53 & 49 & 4 & 25 & 10 \\
\hline Polyarthritis & 53 & 49 & 53 & 25 & 28 \\
\hline Bilateral sacroiliitis & 51 & 43 & 16 & 6 & 0 \\
\hline Bilateral sacroiliitis & 52 & 31 & 10 & 17 & 0 \\
\hline Sacroiliitis (acute stage) & 54 & 70 & 23 & 16 & 6 \\
\hline Sacroiliitis (follow up) & 54 & 45 & 20 & 13 & 8 \\
\hline Back pain & 54 & 105 & 34 & 39 & 15 \\
\hline Chronic back pain & 54 & 105 & 47 & 39 & 14 \\
\hline Urological manifestations & 52 & 31 & 35 & 17 & 6 \\
\hline Urological manifestations & 53 & 49 & 27 & 25 & 4 \\
\hline Urethritis & 54 & 105 & 31 & 39 & 3 \\
\hline Reiter's syndrome & 53 & 49 & 12 & 25 & 0 \\
\hline Reiter's syndrome & 54 & 105 & 37 & 39 & 0 \\
\hline AAU & 51 & 43 & 18 & 6 & 0 \\
\hline Iritis & 52 & 31 & 16 & 17 & 0 \\
\hline Iritis or conjunctivitis & 53 & 49 & 20 & 25 & 0 \\
\hline Ocular manifestations & 54 & 105 & 18 & 39 & 0 \\
\hline Carditis & 52 & 31 & 16 & 17 & 0 \\
\hline Erythema nodosum & 53 & 49 & 2 & 25 & 32 \\
\hline Erythema nodosum & 54 & 105 & 2 & 39 & 21 \\
\hline Yersinia titre & 53 & 49 & 980 (titre) & 25 & 490 (titre) \\
\hline
\end{tabular}


observe their patients in the acute stage of their arthritis and no mention was made of the time between the start of the infection and the onset of the arthritis. Moreover, one third of the patients did not have a history of diarrhoea at all. Stool cultures were not available, normally being positive within the first two weeks from the onset of the symptoms. The yersinia titre remained raised in a number of cases, even when all symptoms cleared. No mention was made of the nature of these antibodies, though it is known that IgG class antibodies may persist for a long time, even for years, in the circulation of these patients. ${ }^{56}$ It is, therefore, difficult to make the diagnosis of $\operatorname{ReA}$ after a yersinia infection in all these cases.

\section{Salmonella}

Available data from the Scandinavian ${ }^{50} 545758$ countries and England ${ }^{59}$ on small numbers of patients with reactive arthritis after salmonella infection showed a significantly increased prevalence $\frac{}{n}$. of B27 of $97 \%$. Heterogeneity between $\mathrm{B} 27^{+}$and B27- after salmonella $\operatorname{ReA}$ was, however, not $\stackrel{\rho}{=}$ observed because of the small numbers available. Data obtained by Leirisalo et $a l^{54}$ showed a clinical picture compatible with complete or incomplete RS (only urethritis) in nine B27 $7^{+}$patients. In two of the nine $\mathrm{B} 27^{+}$patients with salmonella reactive arthritis AS developed four years after the infectious arthritis. ${ }^{54}$

\section{Campylobacter jejuni (Table 3)}

Reactive arthritis associated with Campylobacter jejuni was originally described by Berden et al. 60 Kosunen et al reported eight cases of $\operatorname{ReA}$ among 340 patients with $C$ jejuni diarrhoea. ${ }^{61}$ Four out of five $B 27^{+}$patients showed a polyarthritis and a fourfold increase in agglutinating antibodies against $\mathrm{O}$ $C$ jejuni. Three additional patients, of whom two were $\mathrm{B} 27^{-}$, showed milder symptoms and a lower $z$

Table 3 Differences between $\mathrm{B27}^{+}$and $\mathrm{B27}^{-}$reactive arthritis after Campylobacter jejuni infection

\begin{tabular}{|c|c|c|c|c|c|}
\hline \multirow[t]{2}{*}{ Clinical details } & \multirow[t]{2}{*}{ Reference } & \multicolumn{2}{|l|}{ B27 positive } & \multicolumn{2}{|l|}{ B27 negative } \\
\hline & & Number studied & Prevalence (\%) & Number studied & Prevalence (\%) \\
\hline Men & 62 & 18 & 50 & 13 & 62 \\
\hline Mean duration & 62 & 18 & 110 (days) & 13 & 27 (days) \\
\hline Polyarthritis & 61 & 5 & 80 & 2 & 0 \\
\hline Polyarthritis & 62 & 18 & 50 & 13 & 8 \\
\hline Extra-articular manifestations & 62 & 18 & 50 & 13 & 38 \\
\hline Agglutination titre increased fourfold & 61 & 5 & 80 & 2 & 50 \\
\hline
\end{tabular}

Table 4 Differences between $B 27^{+} R S$ and $B 27^{-} R S^{*}$

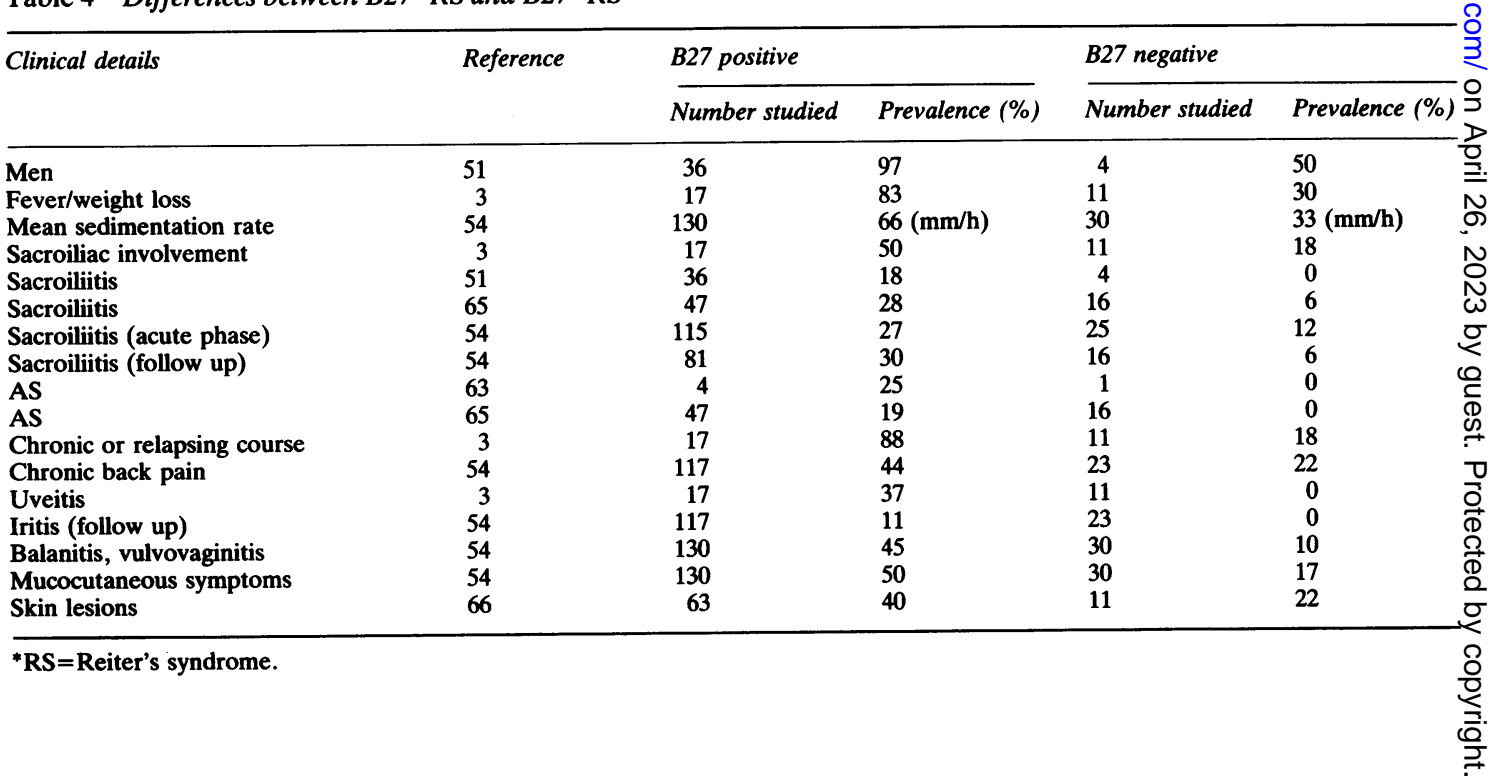


$C$ jejuni titre. Van de Putte et al recently published a review of 19 studies, including their own. ${ }^{62}$ Table 3 shows that compared with their B27- counterparts the $\mathrm{B} 27^{+}$patients more often have polyarthritis of long duration, complicated by extra-articular manifestations and an increase of the agglutination titre. Data on sacroiliac involvement were too scarce to allow any conclusions.

\section{Shigella}

Reactive arthritis after Shigella flexneri infection has an $85 \%$ prevalence of $\mathrm{B} 27$ positivity. ${ }^{51}$ Most patients contract Reiter's disease. ${ }^{51} 63$ Table 4 gives details of disease heterogeneity.

\section{$\mathbf{B 2 7}^{+} \mathbf{R S}$ versus $\mathrm{B27}^{-} \mathbf{R S}$ (Table 4 )}

McClusky et al subdivided 28 patients with Reiter's syndrome into groups based on the course of the disease and extra-articular manifestations. They found a chronic or relapsing course more often in $\mathrm{B} 27^{+} \mathrm{RS}$ patients than in those who were B27- $\mathrm{RS}^{3}$ AS expected, extra-articular manifestations were found in $\mathrm{B} 27^{+} \mathrm{RS}$ patients especially. Aho et al confirmed these observations. ${ }^{51}$ Leirisalo et al found significantly increased balanitis, vulvovaginitis, and mucocutaneous symptoms in $\mathrm{B} 27^{+} \mathrm{RS}$ patients compared with B27- ${ }^{-} .^{54}$ Also, more low back pain and abnormal sacroiliac joints were found in

Table 5 Differences between $B 27^{+} A A U$ and $B 27^{-} A A U^{*}$

\begin{tabular}{|c|c|c|c|c|c|}
\hline \multirow[t]{2}{*}{ Clinical details } & \multirow[t]{2}{*}{ Reference } & \multicolumn{2}{|l|}{ B27 positive } & \multicolumn{2}{|l|}{ B27 negative } \\
\hline & & Number studied & Prevalence (\%) & Number studied & Prevalence (\%) \\
\hline Men & 67 & 51 & 67 & 39 & 50 \\
\hline Men & 70 & 22 & 82 & 11 & 36 \\
\hline Men & 71 & 14 & 67 & 12 & 50 \\
\hline Men & 72 & 76 & 61 & 93 & 59 \\
\hline Men & 76 & 50 & 76 & 10 & 60 \\
\hline Men & 78 & 73 & 71 & 71 & 49 \\
\hline Age at onset & 78 & 73 & 35 (years) & 71 & 43 (years) \\
\hline Mean age & 68 & 12 & 33 (years) & 21 & 43 (years) \\
\hline Duration $>3$ weeks & 67 & 51 & 84 & 39 & 39 \\
\hline Duration $>3$ weeks & 68 & 12 & 75 & 21 & 38 \\
\hline Unilateral & 76 & 50 & 94 & 10 & 50 \\
\hline Unilateral & 78 & 73 & 97 & 71 & 79 \\
\hline Cells in anterior chamber & 67 & 51 & 80 & 39 & 44 \\
\hline Cells in anterior chamber & 78 & 73 & 60 & 71 & 18 \\
\hline Fibrin in anterior chamber & 67 & 51 & 37 & 39 & 8 \\
\hline Fibrin in anterior chamber & 68 & 12 & 100 & 21 & 80 \\
\hline Fibrin in anterior chamber & 76 & 50 & 42 & 10 & 0 \\
\hline Fibrin in anterior chamber & 78 & 73 & 56 & 71 & 10 \\
\hline Mutton fat keratic precipitates & 76 & 50 & 0 & 10 & 60 \\
\hline Mutton fat keratic precipitates & 78 & 73 & 3 & 71 & 32 \\
\hline Ptosis & 67 & 51 & 55 & 39 & 23 \\
\hline Postcrior synechiae & 76 & 50 & 76 & 10 & 30 \\
\hline Posterior synechiae & 78 & 73 & 36 & 71 & 15 \\
\hline Recurrent attacks & 67 & 51 & 45 & 39 & 13 \\
\hline Recurrent attacks & 68 & 12 & 92 & 21 & 43 \\
\hline Recurrent attacks & 71 & 14 & 36 & 12 & 50 \\
\hline Recurrent attacks & 76 & 50 & 60 & 10 & 30 \\
\hline Mean interval between attack & 78 & 73 & 100 (weeks) & 71 & 58 (weeks) \\
\hline Sacroiliitis & 69 & 46 & 35 & 33 & 12 \\
\hline Sacroiliitis & 70 & 22 & 55 & 11 & 27 \\
\hline AS & 67 & 51 & 22 & 39 & 5 \\
\hline AS & 71 & 46 & 20 & 33 & 3 \\
\hline AS & 72 & 76 & 45 & 93 & 8 \\
\hline AS & 78 & 73 & 39 & 71 & 1 \\
\hline RS & 67 & 51 & 8 & 39 & 0 \\
\hline RS & 78 & 73 & 8 & 71 & 0 \\
\hline Low back pain & 72 & 76 & 60 & 93 & 14 \\
\hline Associated rheumatic disease & 76 & 50 & 42 & 10 & 10 \\
\hline Systemic disease & 67 & 51 & 45 & 39 & 13 \\
\hline Systemic disease & 68 & 12 & 42 & 21 & 9 \\
\hline Systemic disease & 70 & 22 & 55 & 11 & 0 \\
\hline Systemic disease & 71 & 14 & 43 & 12 & 8 \\
\hline
\end{tabular}

${ }^{*} \mathrm{AAU}=$ acute anterior uveitis. 
$\mathrm{B} 27^{+} \mathrm{RS}$ than in $\mathrm{B} 27^{-} \mathrm{RS}$. In the follow up period $12 \%$ of the $\mathrm{B} 27^{+} \mathrm{RS}$ patients developed AS in contrast with $6 \%$ of the B27 ${ }^{-}$RS group. A similar increase in disease severity in $\mathrm{B} 27^{+} \mathrm{RS}$ patients was observed by Schultz et al. ${ }^{64}$ They analysed the clinical and HLA antigenic profile of 86 Caucasian and 13 black patients with RS. They tried to determine the predictability of certain clinical RS symptoms by any HLA-A or B antigens, or both. The presence of $B 27$ seemed to make the patient with RS more prone to a large total number of clinical features, such as fever, weight loss, low back pain, AS, heel pain, and chronic peripheral arthritis, in addition to acute peripheral joint involvement, especially when the haplotype A1B27 or A2B27 was present. The presence of $\mathrm{Bw} 35$ seemed to protect against secondary AS in RS and may be the cause of reduced disease severity of RS in black patients, who have a high prevalence of Bw35.

Thirteen years after an initial RS episode Calin and Fries traced and studied five patients with RS out of a group of 10 . Of these five patients with RS, one $\mathrm{B} 27^{-}$patient had minimal disease and was symptom free. The other four $\mathrm{B} 27^{+}$patients had persistent active disease with a chronic course. ${ }^{63}$ Nicholls studied $47 \mathrm{~B} 27^{+}$and 16 B27- men with RS and found more sacroiliitis and AS in the B27 patients. ${ }^{65}$ Willkens et al confirmed this persistent disease activity, finding a subsequent chronic course in $63 \mathrm{~B} 27^{+} \mathrm{RS}$ patients compared with $11 \mathrm{~B} 27^{-} \mathrm{RS}$ patients. ${ }^{66} \mathrm{He}$ observed an increase in skin lesions in $\mathrm{B} 27^{+}$patients as well.

\section{B27 $^{+}$AAU versus B27 $^{-}$AAU (Table 5)}

Mapstone and Woodrow described the clinical features in $51 \mathrm{~B} 27^{+} \mathrm{AAU}$ patients as acute inflammation of short duration, frequently occurring unilaterally, and with a preponderance of men. The severity of the attack was measured by protein extravasation into the anterior chamber and the absence of mutton fat keratic precipitates. ${ }^{6768} \mathrm{~A}$ high prevalence of associated rheumatic disease was observed. ${ }^{67-74}$ This B27 associated AAU has been reported to have a favourable prognosis when compared with HLA-B27- AAU. ${ }^{67} 7576$

The more complicated course of B27- AAU has been attributed to the fact that inflammatory activity in $\mathrm{B} 27^{-} \mathrm{AAU}$ takes more time to resolve. It often becomes chronic, a complication typical of HLAB27- AAU ${ }^{75}$ Currently, AAU has been classified as an iridocyclitis with a duration of three months at the most. ${ }^{77}$ In most studies, however, the term 'acute' has been used to describe the type of inflammation instead of the actual duration of the attack.
Rothova et al studied the clinical features of AAU $\frac{\square}{\circ}$. in $\mathrm{B} 27^{+}$and $\mathrm{B} 27^{-}$patients. ${ }^{78} \mathrm{AAU}$ in this study was defined as an iritis or iridocyclitis that healed $\underset{\sim}{\vec{S}}$ completely within a period of three months. Table $5 \mathrm{O}$ shows that HLA-B27 associated acute AAU is a 흘 separate clinical entity. Frequent recurrent and $\frac{\bar{m}}{\bar{D}}$ unilateral inflammation of alternating eyes develops, $\stackrel{\mathbb{Q}}{\not}$ usually in young men, and is severe in the acute stage but with no mutton fat precipitates. The prevalence of ocular complications increased with $\vec{\circ}$ the number of recurrences. The frequent association $\overrightarrow{\vec{\omega}}$ with seronegative spondyloarthropathies is con- $\omega^{\circ}$ firmed. In the long run, however, visual prognosis did not differ significantly in $\mathrm{B} 27^{+}$or $\mathrm{B} 27^{-} \mathrm{AAU}$ patients.

\section{Discussion}

This review shows that the strong interrelationship 을 of AS, RS, ReA, and AAU, especially in the $\overrightarrow{7}$ presence of B27, is remarkable. In 1974 Moll and Wright suggested calling this group of strongly interrelated diseases 'the seronegative spondarth- $\vec{\phi}$ ritides' ${ }^{79-81}$ It is evident, however, that this name $\infty$ has no reference to AAU, except when AAU is an extra-articular manifestation of AS. Some authors even considered $\mathrm{B} 27^{+} \mathrm{AAU}$ to be a monosymptomatic manifestation or 'forme fruste' of AS. ${ }^{70} 8283$ AAU may be found in all seronegative spondyloarthropathies, with or without sacroiliac joint changes, especially in the presence of B27.2956 79 80 84-86

Radiological sacroiliitis is a necessary condition for the diagnosis of $\mathrm{AS},{ }^{87} 88$ which is why Moll and Wright chose radiological sacroiliitis as the pivotal point of the seronegative spondarthritides. Radiological signs of sacroiliitis may exist, however, without other clinical symptoms of AS. ${ }^{29} 82$ Ankylosis of the spine is not contracted by all patients, ${ }^{85} 8990$ ) and spinal syndesmophytes may exist without radio- $₹$ logical sacroiliitis in $\mathrm{B} 27^{+}$patients, as has been $ᄋ$ postulated by some authors. ${ }^{79}{ }^{80}$ Moreover, sacroili- $D$ itis may be found in all diseases associated with AS, especially in the presence of B27. ${ }^{79}$ Therefore, $\mathbb{N}$ AAU and sacroiliitis may be considered as two clinical features from a vast number of overlapping 0 symptoms occurring in AS and its related diseases, $\omega$ especially in the presence of B27. It may be better to

speak of a syndrome instead of a disease.
The clinical features of this syndrome have been $\stackrel{0}{\mathbb{\Phi}}$ described by Moll and Wright. ${ }^{79-81}$ These features ${ }^{+}$ are common to all diseases associated with AS. $\frac{0}{0}$ Absence of the rheumatoid factor and subcutaneous nodules has been noted. Peripheral arthritis attack- $\frac{\rho}{\Phi}$ ing the joints of the lower extremities and entheso- $\stackrel{\mathbb{Q}}{\varrho}$ pathy of the Achilles tendon often occur during the course of the disease. 


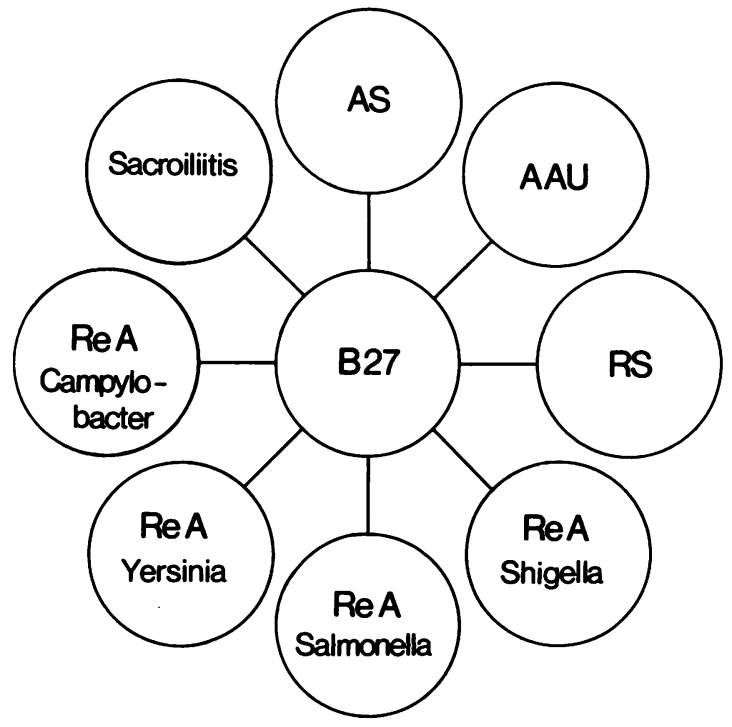

Fig. $1 B 27$ associated diseases. $A S=$ ankylosing spondylitis; $A A U=$ acute anterior uveitis; $R S=$ Reiter's syndrome; $\operatorname{Re} A=$ reactive arthritis.

Dekker-Saeys ${ }^{29}$ and Møller and Berg ${ }^{91}$ suggested the name Bechterew's syndrome for this group of interrelated diseases. HEMRI syndrome (hereditary multifocal relapsing inflammation) has also been suggested as a collective term for the whole group of conditions. ${ }^{92}$ These names, however, do not account for the very important role of B27 in these diseases.

We consider B27 to be the pivotal point of these interrelated diseases, as is shown in Fig. 1, and support the name 'the B27 associated diseases'.

The name gives credit to the clinical symptoms and signs of AS and its related diseases. It offers the clinician the possibility of working with a distinct clinical entity. B27- AS, psoriatic arthritis, and arthritis in association with inflammatory bowel disease may be regarded as resembling strongly the clinical entities of the B27 associated diseases, but with a distinct pathogenesis. The use of such a specific name may, however, dampen or kill the search for other genetic factors, which undoubtedly exist as was mentioned before.

In this way the various interacting aetiological predisposing genetic and environmental factors in disease susceptibility are accounted for. The part B27 plays in disease susceptibility is not known, though many suggestions have been brought forward. Nevertheless, by placing B27 as a genetic marker in the centre of the associated diseases, further clinical and laboratory research to unravel the pathogenic role of this membrane protein may be stimulated.

\section{References}

1 Ebringer A. The cross-tolerance hypothesis, HLA-B27 and ankylosing spondylitis. $\mathrm{Br} J$ Rheumatol 1983; 22 (suppl 2): 53-66.

2 Armstrong R D, Panayi G S, Welsh K I. Histocompatibility antigens in psoriasis, psoriatic arthropathy and ankylosing spondylitis. Ann Rheum Dis 1983; 42: 142-6.

3 McClusky O E, Lordon R E, Arnett F C. HL-A27 in Reiter's syndrome and psoriatic arthritis; a genetic factor in disease susceptibility and expression. $J$ Rheumatol 1974; 1: 263-8.

4 Dausset J, Svejgaard A. HLA and disease. Copenhagen: Munksgaard, 1977: 57.

5 Brewerton D A, Caffrey M, Nicholls A, Walters D, James D C O. HL-A27 and arthropathies associated with ulcerative colitis and psoriasis. Lancet 1974; i: 956-7.

6 Brewerton D A, Caffrey M, Hart F D, James D C O, Nicholls A. Sturrock R D. Ankylosing spondylitis and HL-A27. Lancet 1973; i: 904-7.

7 Møller P, Vinje O, Berg K, Kåss E. Genetic heterogeneity in psoriatic sacroiliitis. Scand J Rheumatol [Suppl] 1979; 32: 193-4.

8 Møller P, Vinje O, Berg, K. HLA antigens, psoriasis and acute anterior uveitis in Bechterew's syndrome (ankylosing spondylitis). Clin Genet 1982; 21: 215-21.

9 Schlosstein L, Terasaki P I, Bluestone R, Pearson C M. High association of an HL-A antigen, w27, with ankylosing spondylitis. N Engl J Med 1973; 288: 704-6.

10 Lochead J A, Chalmers I M, Marshall W H, et al. HLA-B27 haplotypes in family studies of ankylosing spondylitis. Arthritis Rheum 1983; 26: 1011-6.

11 Brewerton D A, Webley M, Milford Ward A. Acute anterior uveitis and the fourteenth chromosome. In: Ziff M. Cohen S B, eds. Advances in inflammation research. Vol 9. The spondyloarthropathies. New York: Raven Press, 1985: 225-31.

12 Linssen A, Rothova A, Broekema N, et al. Genes on chromosome $14 \mathrm{q}$ and their role in the pathogenesis of HLA-B27 associated diseases. Clin Exp Rheumatol 1987; 5 (suppl 1): 85-95.

13 Linssen A, Rothova A, Luyendijk L. Kijlstra A, Feltkamp T E W, Valkenburg H A. Epidemiologic study of acute anterior uveitis (AAU) and its relation to ankylosing spondylitis (AS) and HLA-B27. Preliminary results of a prospective study in the Netherlands. In: Seronegative polyarthritis. Rome: Cic Edizioni Internationali, 1986: 49. (Eular symposium).

14 Linden S J M van der, Valkenburg H A, Jong B M de, Cats A. The risk of developing ankylosing spondylitis in HLA-B27 positive individuals. Arthritis Rheum 1984; 27 : 241-9.

15 Grumet F C, Calin A, Engleman E G, Fish L, Foung S F H. Studies of HLA-B27 using monoclonal antibodies: ethnic and disease-associated variants. In: Ziff $\mathbf{M}$, Cohen S B, eds. Advances in inflammation research. Vol 9. The spondyloarthropathies. New York: Raven Press, 1985: 41-55.

16 Breur-Vriesendorp B S, Huis B, Dekker-Saeys A J, Breuning M H, Ivanyi P. Subtypes of antigen HLA-B27 (B27w and B27k) defined by cytotoxic T-lymphocytes: identification of a third subtype (B27c) prevalent in oriental populations. In: Ziff $M$, Cohen S B, eds. Advances in inflammation research. Vol 9. The spondyloarthropathies. New York: Raven Press, 1985: 55-67.

17 Taurog J D, Miyachi Y, Nicklas J A, et al. Studies of HLA-B27 with anti-B27 cytolytic T-cell clones and HLA loss mutants of a B27 positive lymphoblastoid cell line. In: Ziff $M$, Cohen S B, eds. Advances in inflammation research. Vol 9. The spondyloarthropathies. New York: Raven Press, 1985: 67-75.

18 Breur-Vriesendorp B S, Neefjes J C, Huis B, Seventer G A van, Ploegh H L, Ivanyi P. Identification of new B27 subtypes 
(B27C and B27D) prevalent in Oriental populations. Hum Immunol 1986; 16: 163-8.

19 Khan M A. Spondylarthropathies in non-Caucasian populations of the world. In: Ziff $\mathrm{M}$, Cohen S B, eds. Advances in inflammation research. Vol 9. The spondyloarthropathies. New York: Raven Press, 1985: 91-101

20 Ebringer A, Baines $M$, Childerstone $M$, Chuloom $M$, Ptaszynska T. Etiopathogenesis of ankylosing spondylitis and the cross-tolerance hypothesis. In: Ziff $\mathbf{M}$, Cohen S B, eds. Advances in inflammation research. Vol 9. The spondyloarthropathies. New York: Raven Press, 1985: 101.

21 Keat A. Is spondylitis caused by klebsiella? Immunology Today 1986; 7: 144-8.

22 Good A E, Kawanishi H, Schultz J S. HLA-B27 in blacks in ankylosing spondylitis or Reiter's disease. N Engl J Med 1976; 294: 166-7.

23 Khan M A, Kushner I, Braun W E. Comparison of clinical features in HLA-B27 positive and negative patients with ankylosing spondylitis. Arthritis Rheum 1977; 20: 909-12.

24 Khan M A, Kushner I, Braun W E. Association of HLA-A2 with uveitis in HLA-B27 positive patients with ankylosing spondylitis. J Rheumatol 1981; 8: 295-8.

25 Nahir M, Scharf Y, Brik R, Scharf Y, Gidoni O, Barzilai A. The influence of HLA-B27 on the clinical picture of ankylosing spondylitis. Rheumatol Rehabil 1979; 18: 10-12.

26 Scharf J, Nahir M, Scharf J, et al. Anterior uveitis in ankylosing spondylitis: a histocompatibility study. Ann Ophthalmol 1979; 11: 1061-2.

27 Linden J M J P van der, Ceulaer $\mathrm{K}$ de, Romunde L K J van, Cats A. Ankylosing spondylitis without HLA-B27. J Rheumatol 1977; 4 (suppl 3): 54-6.

28 Gerber N, Ambrosini G D, Boni A, Fehr K, Wagenhauser F J. Spondylitis ankylosans (Bechterew) und gewebsantigen HLAB27. Z Rheumatol 1977; 36: 224-9.

29 Dekker-Saeys A J. Spondylitis ankylopoietica-syndroom, een onderzoek naar het verband tussen spondylitis ankylopoietica en inflammatoire darmziekten (Ankylosing spondylitis and its relation to inflammatory bowel diseases). Amsterdam: Academic Press, 1976: 140. (Thesis)

30 Woodrow J C, Eastmond C J. HLA-B27 and the genetics of ankylosing spondylitis. Ann Rheum Dis 1978; 37: 504-9.

31 Wagener P, Mau W, Zeidler H, Eckert G, Robin-Winn M, Deicher H. HLA-B27 and clinical aspects of ankylosing spondylitis: results of prospective studies. Immunol Rev 1985 86: 93-9.

32 Arnett F C Jr, Hochberg M C, Bias W B. Cross-reactive HLAantigens in B27 negative Reiter's syndrome and sacroiliitis. John Hopkins Medical Journal 1977; 141: 193-7.

33 Khan M A, Kushner I, Braun W E. Genetic heterogeneity in primary ankylosing spondylitis. J Rheumatol 1980; 7: 383-6.

34 Khan M A, Braun W E, Kushner I, Grecek D E, Muir W A Steinberg A G. HLA-B27 in ankylosing spondylitis: differences in frequency and relative risk in American blacks and Caucasians. J Rheumatol 1977; 4 (suppl 3): 39-43.

35 Khan M A, Kushner I, Braun W E. A subtype of ankylosing spondylitis associated with HLA-B27 in American blacks. Arthritis Rheum 1978; 21: 528-30.

36 Berg-Loonen E M van der, Dekker-Saeys A J, Meuwissen S G M, Nijenhuis L E, Engelfriet C P. Histocompatibility antigens and other genetic markers in ankylosing spondylitis and inflammatory bowel diseases. Immunogenetics 1977; 4: 167-75.

37 Espinoza L R, Vasey F B, Oh J H, Wilkinson R, Osterland C K. Association between HLA-Bw38 and peripheral psoriatic arthritis. Arthritis Rheum 1978; 21: 72-5.

38 Woodrow J C. Genetic aspects of the spondylarthropathies. In Panayi G S, ed. Clinics in rheumatic diseases. Vol 11. Seronegative spondylarthropathies. London, Philadelphia, Toronto Saunders, 1985: 1-24.

39 Mielants H, Veys E, Joos R, Naens L, Cuvelier C, Vos M de.
HLA-Bw62 in reactive arthritis and ankylosing spondylitis: relation to gut inflammation. In: Seronegative polyarthritis. Rome: Cic Edizioni Internationali, 1986: 29. (Eular symposium.)

40 Wagener $P$, Zeidler $H$, Eckert $G$, Deicher $H$. Increased frequency of HLA-Bw35 CREG antigens in HLA-B27 negative ankylosing spondylitis. Br J Rheumatol 1983; 22 (suppl 2): 134-5.

41 Jajić I, Kerhin V, Kaštelan A. Ankylosing spondylitis syndrome in patients without HLA-B27. Br J Rheumatol 1983; 22 (suppl 2): 136 .

42 Edmonds J, Bashir H, Thomson G, Carbonara A O. HLA-B27 $\vec{O}$ negative ankylosing spondylitis. In: Albert E D, ed. Histocompatibility testing 1984. Berlin, Heidelberg: Springer, 1984: 388-94.

43 McKendry R J M. Sengar D P S, Des Groseilliers J P, Dunne J V. Frequency of HLA antigens in patients with psoriasis or psoriatic arthritis. Can Med Assoc J 1984; 130: 411-4.

44 Møller P, Berg K, Vinje O. HLA phenotypes, and joint affection in psoriasis, acute anterior uveitis and chronic prostatitis. Clin Genet 1981; 19: 266-70.

45 Espinoza L R, Vasey F B, Gaylord S W, et al. Histocompatibility typing in seronegative spondyloarthropathies: a survey. Semin Arthritis Rheum 1982; 11: 375-81.

46 Metzger T A, Rodnan G P, Rabin B, Birnbaum N, Porter P. HLA-A antigen B27 and psoriatic arthritis. Arthritis Rheum 1974; 17: 323

47 Bluestone R, Morris R I, Metzger A L, Terasaki P I. (HL-A) $\vec{\bullet}$ w27 and the spondylitis of chronic inflammatory bowel disease $\infty$ and psoriasis. Ann Rheum Dis 1975; 34 (suppl 1): 31-2.

48 Russell A S, Schlaut J, Percy J S, Dossetor J B. HL-A transplantation antigens in ankylosing spondylitis and Crohn's disease. J Rheumatol 1974; 1: 203-9.

49 Hyla J F, Franck W A, Davis J S. Lack of association of HLAB27 with radiographic sacroiliitis in inflammatory bowel disease. J Rheumatol 1976; 3: 196-200.

50 Aho K, Ahvonen P, AlkioP, Sairanen E, Sievers K, Tiilikainen A HL-A27 in reactive arthritis following infection. Ann Rheum Dis 1975; 34 (suppl 1): 29-30.

51 Aho K, Ahvonen P, Lassus A, Sievers K, Tiilikainen A. HLA27 in reactive arthritis: a study of yersinia arthritis and Reiter's disease. Arthritis Rheum 1974; 17: 521-6.

52 Leirisalo $M$, Laitinen $O$, Tiilikainen A. HLA phenotypes in patients with rheumatic fever, rheumatic heart disease and yersinia arthritis. J Rheumatol 1977; 4 (suppl 3): 78-83.

53 Laitinen O, Leirisalo M, Skylv G. Relation between HLA-B27 and clinical features in patients with yersinia arthritis. Arthritis Rheum 1977; 20: 1121-4.

54 Leirisalo M, Skylv G, Kousa M, et al. Follow-up study on patients with Reiter's disease and reactive arthritis with special reference to HLA-B27. Arthritis Rheum 1982; 25: 249-58.

55 Dequeker J, Jamar R, Walravens M. HLA-B27, arthritis and Yersinia enterocolitica infection. $J$ Rheumatol 1980; 7: 706-10.

56 Aho K, Leirisalo-Repo $M$, Repo $H$. Reactive arthritis. In: O Panayi G S, ed. Clinics in rheumatic diseases. Vol 11. Sero- $N$ negative spondylarthropathies. London, Philadelphia, Toronto: Saunders, 1985: 35.

57 Friis J, Svejgaard A. Salmonella arthritis and HL-A27. Lancet $1974 ;$ i: 1350.

58 Håkansson U, Low B, Eitrem R, Winblad S. HL-A27 reactive arthritis in an outbreak of salmonellosis. Tissue Antigens 1975; 6: $366-7$

59 Robitaille A, Cockburn C, James D C O, Ansell B M. HLA T frequencies in less common arthropathies. Ann Rheum Dis 1976; 35: 271-3.

60 Berden J H, Muytjens H L, Putte L B A van de. Reactive arthritis associated with Campylobacter jejuni enteritis. $\mathrm{Br} \mathrm{Med} \mathrm{J} \varrho$ 1979 ; i: $380-1$.

61 Kosunen T U, Kauranen O, Martio J, et al. Reactive arthritis $\bigcirc$

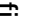
. 
after Campylobacter jejuni enteritis in patients with HLA-B27. Lancet 1980; i: 1312-3.

62 Putte L B A van de, Riel P L C M van. Reactive arthritis associated with Campylobacter enteritis. In: Veys $\mathbf{E} \mathbf{M}$, Mielants H, eds. Spondyloarthropathies. Involvement of the gut. Amsterdam: Excerpta Medica/Elsevier, 1987: 97-102.

63 Calin A. Fries J F. An 'experimental' epidemic of Reiter's syndrome revisited. Follow-up evidence on genetic and environmental factors. Ann Intern Med 1976; 84: 564-6.

64 Schultz J S, Good A E, Sing C F, Kapur J J. HLA-profile and Reiter's syndrome. Clin Genet 1981; 19: 159-67.

65 Nicholls A. Reiter's disease and HL-A27. Ann Rheum Dis 1975; 34 (suppl): 27-8.

66 Willkens R F, Arnett F C, Bitter T. et al. Reiter's syndrome. Evaluation of preliminary criteria for definite disease. Arthritis Rheum 1981; 24: 844-9.

67 Mapstone R, Woodrow J C. HL-A27 and acute anterior uveitis. Br J Ophthalmol 1975; 59: 270-5.

68 Zervas J, Tsokos G, Papadakis G, Kabouklis E, Papadopoulos D. HLA-B27 frequency in Greek patients with acute anterior uveitis. Br J Ophthalmol 1977; 61: 699-701.

69 Russell A S, Lentle B C, Dossetor J B. Acute anterior uveitis. A clinical, HLA and scintiscan survey. Acta Rheumatol 1979; 3: 156-63.

70 Møller P, Vinje O, Olsen E G. HLA-B27, sacroiliitis and peripheral arthropathy in acute anterior uveitis. Scand $J$ Rheumatol 1980; 9: 234-6.

71 Wakefield D, Robinson P, Easter J, Graham D, Penny R. Decreased chemiluminescent associated phagocytic response of peripheral blood mononuclear cells to Chlamydia trachomatis in patients with HLA-B $27^{+}$anterior uveitis. $\mathrm{Br} J$ Rheumatol 1985; 24: 332-9.

72 Beckingsdale A B, Davies J, Gibson J M, Rosenthal A R. Anterior uveitis, ankylosing spondylitis, back pain and HLAB27. Br J Ophthalmol 1984; 68: 741-5.

73 Linssen A, Dekker-Saeys A J, Dandrieu M R, et al. Possible ankylosing spondylitis in acute anterior uveitis. $\mathrm{BrJ}$ Rheumatol 1983; 22 (suppl 2): 137-43.

74 Linssen A, Dekker-Saeys A J. Dijkstra P F, et al. The use of HLA-B27 as a diagnostic and prognostic aid in acute anterior uveitis in the Netherlands. Doc Ophthalmol 1986; 64: 217-23.

75 Rothova A, Kijlstra A. Buitenhuis H J, Gaag R van der, Feltkamp T E W. HLA-B27 associated uveitis-A distinct clinical entity? In: Saari K M, ed. Uveitis update. Amsterdam: Excerpta Medica/Elsevier, 1984: 91-5.

76 Saari K M. Acute anterior uveitis. In: Saari K M, ed. Uveitis update. Amsterdam: Excerpta Medica/Elsevier, 1984: 79-90.

77 O'Connor C R. Current classification of uveitis. In: Saari K M, ed. Uveitis update. Amsterdam: Excerpta Medica/Elsevier, 1984: 3-6.

78 Rothova A, Veenendaal W G van, Linssen A, Glasius E, Kijlstra A, Jong P T V M de. Clinical features of acute anterior uveitis. Am J Ophthalmol 1987; 103: 137-45.

79 Moll J M H, Haslock I, Macrae I F, Wright V. Associations between ankylosing spondylitis. psoriatic arthritis, Reiter's disease, the intestinal arthropathies and Behçet's syndrome. Medicine (Baltimore) 1974; 53: 343-64.

80 Wright V. Relationship between ankylosing spondylitis and other spondarthritides. In: Moll J M H, ed. Ankylosing spondylitis. Edinburgh, London, Melbourne, New York: Churchill Livingstone, 1980: 42-51.

81 Moll J M H, Haslock I, Wright V. Seronegative spondarthritides. In: Scott J T, ed. Copeman's textbook of the rheumatic diseases. Edinburgh, London, Melbourne, New York: Churchill Livingstone, 1986: 738.

82 Kåss E. Diagnostic criteria in spondylarthritis ankylopoietica. Acta Rheumatologica Scandinavica 1968; 14: 197-209.

83 Brewerton D A, Nicholls A, Caffrey M. Walters D, James D CO. Acute anterior uveitis and HL-A27. Lancet 1973; ii: 994-6.

84 Roger Laurent M. Psoriatic arthritis. In: Panayi G S, ed. Clinics in rheumatic diseases. Vol 11. Seronegative spondylarthropathies. London, Philadelphia, Toronto: Saunders, 1985: 72.

85 Møller P, Vinje O, Kåss E, Berg K. The distribution of clinical findings in Bechterew's syndrome (ankylosing spondylitis) suggests distinct genetic subgroups. Clin Genet 1982; 22: 151-9.

86 Moll J M H. Inflammatory bowel disease. In: Panayi G S, ed. Clinics in rheumatic diseases. Vol 11. Seronegative spondylarthropathies. London, Philadelphia, Toronto: Saunders, 1985: 94-9.

87 Kellgren J H. Diagnostic criteria for population studies in the rheumatic diseases: new diagnostic criteria. Bull Rheum Dis 1962; 3: 291-2.

88 Bennett P H, Burch T A. New York symposium on population studies in the rheumatic diseases: new diagnostic criteria. Bull Rheum Dis 1967; 17: 453-8.

89 Emery A W H, Lawrence J S. Genetics of ankylosing spondylitis. J Med Genet 1967; 4: 239-44.

90 Møller P, Vinje O, Berg K, Kåss E. Genetic heterogeneity in psoriatic sacroiliitis. Scand J Rheumatol [Suppl] 1979; 32: 193-4.

91 Møller P, Berg K. Family studies in Bechterew's syndrome (ankylosing spondylitis). III. Genetics. Clin Genet 1983; 24: 73-89.

92 Møller P, Berg K. Seronegative arthropathy and associated diseases-A multigenic syndrome? Br J Rheumatol 1983; 22 (suppl 2): 5-11. 